\title{
The effect of different forms of iodine on the blood parameters of sheep
}

\author{
O.K. Gogaev ${ }^{*}$ A.R. Demurova, B.K. Ikoeva, E.A. Tokhtieva
}

Gorsky State Agrarian University, 37 Kirov Street, Vladikavkaz, 362040, Russian Federation, *Corresponding author e-mail- texmen2@mail.ru;

Journal of Livestock Science (ISSN online 2277-6214) 11: 40-44

Received on 24/10/2019; Accepted on 17/1/2020

doi. 10.33259/JLivestSci.2020.40-44

\begin{abstract}
Iodine is an extremely important substance for living beings, which has a versatile biological activity and provides functional activity of almost all body systems due to participation in metabolism. The use of inorganic compounds of iodine salts is not always effective enough, as they are unstable, easily oxidized in air, as a result, the content of available iodine significantly reduces. In this regard, a promising direction in the correction of iodine deficiency is the use of organic forms of iodine, when the element is in chemical connection with any organic substance. Nowadays the work in this direction is conducted in Limited liability company "Phili N-Pharm" (Moscow) they let out the iodine-containing additives "Yoddar" and "Yoddar-Zn". The scientific and economic experience to study the impact of different forms of iodine feedings on the productivity of lactating sheep of Tushin breed was conducted in the Joint stock company "Saniba" the suburban district of the Republic of North OssetiaAlania in the period from 2016 to 2017. For the experiment, 40 purebred young ewes, originating from first-class ewes and one inseminator sheep, were selected at birth. All the lambs were divided into 4 groups with 10 lambs in each: one control group and three experimental groups. The maintenance and feeding conditions of all groups were similar; the only difference was that the experienced young ewes' groups received different iodine medicaments in addition to their diet. The amount of iodine fertilizing was added to the feed based on the calculation of $2 \mathrm{mg}$ of iodine per $1 \mathrm{~kg}$ of dry matter of the diet. Feed iodine supplements had a positive effect on the hematopoietic organs: their use helped to improve the overall condition of the blood: the number of red blood cells increased by $1.4-6.7 \%$, hemoglobin-by 5.3-8.8\% and leukocytes-by 4.4-7.6\%. The best results on these indicators were obtained in lambs of experimental groups receiving "Yoddar- $\mathrm{Zn".}$
\end{abstract}

Key words: blood parameters; iodine; "Yoddar-Zn"; "Yoddar"; kayod, distant-mountain keeping, sheep. 


\section{Introduction}

High economic requirements to profitability of production in market conditions force livestock breeders to use more advanced technologies providing the maximum level of animals' productivity, the effective use of fodder means and the decrease of the production expenses. One of the conditions for obtaining cheap and high-quality products is the use of diets balanced by a large number of nutrients, minerals and biologically active substances (Volynkina et al., 2013).

The issues of mineral nutrition occupy an important place in the general complex of full-fledged feeding. The studies of a number of scientists have established a low content of some macro-and microelements in the biosphere of the natural and climatic zone of the Central Caucasus. The region is characterized by the endemic diseases, lower rates of productivity and feeding conversion. The average iodine content in the main components of the RSO-Alania biosphere is significantly inferior to the data of the central black earth zone-the reference zone for iodine in Russia. Thus, the concentration of iodine in the soil of our region is inferior to 5.5-12.2 times, in plants this difference is 1.4-12.1, in water-2.7-15.0 times and in the air up to 11 times (Kisinev et al., 2002).

The sheep from the area with a low content of iodine and vitamins, have a lack of hormone-forming function of the thyroid gland (Petrov et al., 2015), respectively, the indicators of viability and productivity decrease.

High quality products can be obtained only from healthy animals and here an important role is played by providing animals with iodine. Iodine affects all metabolic processes in animals with the help of iodine-containing thyroid hormones (Abilov et al., 2016; Gogaev et al., 2018; Kesaev et al., 2017; Kessaev et al., 2015; Kessaev et al., 2013; Kessaev et al., 2013; Kessaev et al., 2011; Gogaev et al., 2019; Gogaev et al., 2019).

The use of inorganic compounds of iodine salts is not always effective enough, as they are unstable, easily oxidized in air, resulting in the content of available iodine is significantly reduced. In this regard, a promising direction in the correction of iodine deficiency is the use of organic forms of iodine, when the element is in chemical connection with any organic substance. In this direction the work is conducted in Limited liability company "Fili NPharm" (Moscow) and now they let out iodine-containing additives "Yoddar" and "Yoddar-Zn".

Therefore present study was undertaken to determine the effect of different forms of iodine-containing medicaments on the morphological parameters of Tushin sheep's blood.

\section{Materials and Methods}

The scientific and economic experience to study the impact of different forms of iodine feedings on the productivity of lactating of Tushin breed sheep was conducted in the Joint stock company "Saniba" the suburban district of the Republic of North Ossetia-Alania in the period from 2016 to 2017. For the experiment, 40 purebred young ewes were selected at birth, originating from first-class ewes and one ram-producer. All the lambs were divided into 4 groups with 10 lambs in each: one control group and three experimental groups. The maintenance and feeding conditions of all groups were the same, the only difference was that the youngster' groups received different iodine medicaments in addition to their diet. The basic diet was made according to "The Norms and Rations of Feeding of Farm Animals" (Kalanikov et al., 2003).

Group 1 (control) - feeding, adopted in the farm-BD -the basic diet;

Group 2-BD + "Kayod";

Group 3-BD + "Yoddar"

Group 4-BD + "Yoddar-Zn".

The amount of iodine fertilizing was added to the feed based on the calculation of $2 \mathrm{mg}$ of iodine per $1 \mathrm{~kg}$ of dry matter of the diet.

Kayod -iodine-containing medicament, which as an active substance, contains $6 \mathrm{mg}$ of potassium iodide, stabilized with sodium bicarbonate in table salt. Composition tablets weighing $0.2 \mathrm{~g}$ contain 1 tablet as an active substance potassium iodide- $6.0 \mathrm{mg}$, and as excipients: magnesium carbonate- $4.4 \mathrm{mg}$; magnesium sulfate- $4.0 \mathrm{mg}$; sodium thiosulfate-3.0 mg; calcium stearate-2.0 mg; talc-6.0 mg; lactose-174.6 mg.

Yoddar" - the feeding additive in the form of organic iodine compounds with milk proteins. One gr. of feeding additive contains $830 \pm 100 \mathrm{mcg}$ of iodine. Ingredients: Iodized milk protein, lactose, potato starch, calcium stearate.

"Yoddar-Zn" - iodized milk protein with zinc, lactose, potato starch and calcium stearate. One gr. of feeding additive "YODDAR-Zn" contains $50 \pm 10 \mathrm{mcg}$ of iodine and $17.5 \pm 2.5 \mathrm{mcg}$ of zinc. Ingredients: Iodized milk protein with zinc, lactose, potato starch, calcium stearate.

The study of hematological indicators was carried out monthly by taking blood from the ear vein early in the morning before feeding, when the animals were at rest. The amount of hemoglobin was determined, erythrocytes and leukocytes were also counted in the taken blood samples.

The number of red blood cells in the blood during the life of the animal does not remain constant, but changes under the influence of various internal and external factors. The formation of red blood cells is due to the presence 
of iron, copper, vitamin B12 in the consumed feed, etc. the lack of these substances in the diet entails a decrease in the number of red blood cells, and the duration of their existence reduces.

\section{Results and discussion}

From the data of table 1 it can be seen that the number of red blood cells is in different periods at different levels. At the beginning of the experiment, all groups of lambs had relatively the same number of red blood cells: in the control group - 11.20; the first-11.12; in the second-11.15 and in the third-11.20 $10^{12} \mathrm{~g} / 1$. Then there is a decrease in their number until the fourth month of life. At 4 months, in the control groups they were: -10.00 ; the first-10.17; the second-10.23 and the third $-10.3010^{12} \mathrm{~g} / \mathrm{l}$. The decrease in groups occurred, respectively, by 10.71 ; $8.54 ; 8.25$ and $8.03 \%$.

Despite the general downward trend, the differences in the content of red blood cells between the control and the experimental groups of lambs in favor of the latter were as follows: the first-1.7; the second-2.3; the third$3.0 \%$. On the fifth month there is a sharp increase in the number of red blood cells in all groups: in control group it reaches 11.50; the first -11.83 ; the second -11.93 ; the third- $12.0510^{12} \mathrm{~g} / \mathrm{l}$ and it respectively increased by: 15.00 ; $16.32 ; 16.62 ; 16.99 \%$ compared with the age of 4 months.

The increase in red blood cells at this age is associated with the driving of sheep to summer high-altitude pastures. The difference between the control and the experiment groups was: the first -2.87 ; the second-3.74; the third- $4.78 \%$. Here we observe a gradual increase in red blood cells in the experimental groups in relation to the control.

At the age of 5 to 8 months there is a gradual decrease in the number of red blood cells, and in the period from 8 to 9 months it is expressed more sharply, due to the overtaking of sheep from mountain pastures to the plane. At the age of 9 months, their content in the blood of lambs of the control group was -9.60 ; the first and the second 10.10; the third group $-10.3510^{12} \mathrm{~g} / \mathrm{l}$. The difference in favor of the experimental groups compared to the control was: the first and the second -5.21 ; the third $-10.94 \%$. By the end of the experiment, i.e. to the 12-months of lambs, the number of red blood cells was 9.67, the first experimental; the second experimental group -9.79 and the third experimental group- $10.0110^{12} \mathrm{~g} / \mathrm{l}$, that is, $3.09 ; 4.37$ and $6.78 \%$ more than in animals of the control group.

Analyzing the obtained data, we see that for the entire study period the number of red blood cells was greater in the blood of animals from experimental groups, than in the blood of lambs from the control group, that is, in young ewes which have received iodine preparations of especially organic form with feed.

The results suggest a beneficial effect of iodine preparations on increasing the number of red blood cells and strengthening metabolic processes in the body of lambs. Hemoglobin is the main transporter of oxygen to the tissues and organs of the animal. The amount of hemoglobin in the blood is unstable and depends on the quality of food, climate, season and other factors.

As it can be seen from the data of table 1, the hemoglobin content in the blood of lambs of all groups is within normal limits. With age, the amount of it begins to decline. To 4-month aged lambs the decrease was: in control group- 16.8; the first -5.25; the second-4.63 and the third-15.17\%. As a result of driving sheep to highmountain pastures, the amount of hemoglobin increased in the control group to 117.5; the first $-122.2 \%$; the second124.4 and the third - $124.2 \mathrm{~g} / \mathrm{l}$. The increase occurred: in the control group by 12.98 ; the first-14.74; the second16.04; the third-19.42\% compared with the data of lambs on the plane. In the same period, there is a difference in the content of hemoglobin in the blood of lambs of the control and experimental groups. It was: in the first -4.00 ; the second-5.87 and the third-5.70\% in favor of the experimental groups. The greatest difference in comparison with the animals of the control group was found in young ewes of the second and the third experimental groups, which have received "Yoddar" and "Yoddar-Zn" in their diets. Starting from the fifth month there is a gradual decrease in hemoglobin content in the blood of lambs from all groups, and in the ninth month we observe a more dramatic decrease in hemoglobin associated with the overtaking of sheep to the plane. This decrease occurred in the control group to 100.0; the first-105.3; the second-102.3 and the third-102.9 g/l. The difference between the control and experimental groups in this age was as follows; the first-5.90; the second-2.30 and the third-2.9\%.

As it can be seen, by the ninth month, the difference between the control and experimental groups is somewhat smoothed. At the end of the experience at 12 months of age, the content of hemoglobin was as follows: the control group-94.0; the first-99.5; the second-101.0 and the third-102.3 g/l, the difference in the direction of the increase was: in the first experimental -5.85 ; the second-7.45 and the third-8.83\%.

There is a general pattern in the change in the amount of hemoglobin associated with age and other factors of the groups. In addition, there is a tendency to increase the amount of hemoglobin in lambs of experimental groups. The difference in the content of hemoglobin increases between the animals of the control and experimental groups from 1 month to 4 months of age, then there is a decrease in this difference to 9 months of age, after which this difference increases again.

The protective functions in the animal body are performed by the elements of white blood cells-leukocytes. The number of them throughout the life of the animal is unstable and varies depending on the physiological state of the animal, the age, feeding and other factors.

The determination of the number of white blood cells in our study was carried out monthly in order to establish the effect of various iodine supplements on the leukocyte index. 
Table 1- The Changes in the blood parameters of Young Ewes

\begin{tabular}{|c|c|c|c|}
\hline \multirow{2}{*}{$\begin{array}{l}\text { Age, } \\
\text { months }\end{array}$} & \multicolumn{3}{|c|}{ Indicator } \\
\hline & $\begin{array}{c}\text { Red Blood } \\
\text { Cells, } 10^{12} \mathrm{~g} / 1\end{array}$ & $\begin{array}{l}\text { Hemoglobin, } \\
\mathrm{g} / \mathrm{l}\end{array}$ & Leukocytes, $10^{9} \mathrm{~g} / 1$ \\
\hline \multicolumn{4}{|c|}{ Control Group } \\
\hline 1 & $11.20 \pm 0.282$ & $125.0 \pm 0.28$ & $9.20 \pm 0.210$ \\
\hline 2 & $10.61 \pm 0.332$ & $105.5 \pm 0.34$ & $8.80 \pm 0.233$ \\
\hline 3 & $10.13 \pm 0.416$ & $104.7 \pm 0.34$ & $8.10 \pm 0.244$ \\
\hline 4 & $10.00 \pm 0.315$ & $104.0 \pm 0.34$ & $7.60 \pm 0.198$ \\
\hline 5 & $11.50 \pm 0.452$ & $117.5 \pm 0.032$ & $7.20 \pm 0.182$ \\
\hline 6 & $11.11 \pm 0.521$ & $115.0 \pm 0.30$ & $7.25 \pm 0.189$ \\
\hline 7 & $10.89 \pm 0.435$ & $112.5 \pm 0.30$ & $7.10 \pm 0.184$ \\
\hline 8 & $10.75 \pm 0.413$ & $111.5 \pm 0.31$ & $7.15 \pm 0.199$ \\
\hline 9 & $9.60 \pm 0.404$ & $100.0 \pm 0.28$ & $7.45 \pm 0.183$ \\
\hline 10 & $9.50 \pm 0.248$ & $97.5 \pm 0.27$ & $7.56 \pm 0.197$ \\
\hline 11 & $9.41 \pm 0.348$ & $97.0 \pm 0.27$ & $8.00 \pm 0.204$ \\
\hline 12 & $9.38 \pm 0.352$ & $94.0 \pm 0.317$ & $7.85 \pm 0.195$ \\
\hline \multicolumn{4}{|c|}{ I Group } \\
\hline 1 & $11.12 \pm 0.374$ & $112.4 \pm 0.32$ & $9.15 \pm 0.358$ \\
\hline 2 & $10.32 \pm 0.459$ & $109.4 \pm 0.32$ & $9.21 \pm 0.356$ \\
\hline 3 & $10.22 \pm 0.443$ & $109.3 \pm 0.33$ & $8.67 \pm 0.368$ \\
\hline 4 & $10.17 \pm 0.429$ & $106.5 \pm 0.33$ & $8.00 \pm 0.393$ \\
\hline 5 & $11.83 \pm 0.350$ & $122.2 \pm 0.33$ & $7.81 \pm 0.355$ \\
\hline 6 & $11.25 \pm 0.437$ & $116.2 \pm 0.34$ & $7.69 \pm 0.383$ \\
\hline 7 & $11.07 \pm 0.256$ & $114.0 \pm 0.34$ & $7.61 \pm 0.399$ \\
\hline 8 & $11.04 \pm 0.317$ & $113.4 \pm 0.31$ & $7.75 \pm 0.318$ \\
\hline 9 & $10.10 \pm 0.637$ & $105.3 \pm 0.33$ & $8.15 \pm 0.363$ \\
\hline 10 & $9.99 \pm 0.320$ & $101.7 \pm 0.28$ & $8.22 \pm 0.365$ \\
\hline 11 & $9.89 \pm 0.262$ & $101.6 \pm 0.28$ & $8.60 \pm 0.354$ \\
\hline 12 & $9.67 \pm 0.300$ & $99.5 \pm 0.30$ & $8.43 \pm 0.336$ \\
\hline \multicolumn{4}{|c|}{ II Group } \\
\hline 1 & $11.15 \pm 0.512$ & $112.4 \pm 0.35$ & $9.22 \pm 0.324$ \\
\hline 2 & $10.39 \pm 0.471$ & $109.3 \pm 0.35$ & $9.11 \pm 0.326$ \\
\hline 3 & $10.26 \pm 0.454$ & $108.4 \pm 0.32$ & $8.61 \pm 0.335$ \\
\hline 4 & $10.23 \pm 0.414$ & $107.2 \pm 0.30$ & $7.90 \pm 0.350$ \\
\hline 5 & $11.93 \pm 0.438$ & $124.4 \pm 0.34$ & $7.58 \pm 0.326$ \\
\hline 6 & $11.51 \pm 0.422$ & $117.4 \pm 0.35$ & $7.62 \pm 0.324$ \\
\hline 7 & $11.21 \pm 0.415$ & $115.2 \pm 0.37$ & $7.57 \pm 0.335$ \\
\hline 8 & $11.01 \pm 0.401$ & $114.0 \pm 0.31$ & $7.66 \pm 0,328$ \\
\hline 9 & $10.10 \pm 0.504$ & $102.3 \pm 0.32$ & $7.96 \pm 0.282$ \\
\hline 10 & $9.99 \pm 0.352$ & $102.1 \pm 0.32$ & $8.05 \pm 0.338$ \\
\hline 11 & $9.98 \pm 0.372$ & $102.1 \pm 0.31$ & $8.63 \pm 0.328$ \\
\hline 12 & $9.79 \pm 0.344$ & $101.0 \pm 0.29$ & $8.69 \pm 0.322$ \\
\hline \multicolumn{4}{|c|}{ III Group } \\
\hline 1 & $11.20 \pm 0.512$ & $122.6 \pm 0.21$ & $9.17 \pm 0.347$ \\
\hline 2 & $10.65 \pm 0.612$ & $107.3 \pm 0.28$ & $9.20 \pm 0.3554$ \\
\hline 3 & $10.41 \pm 0.604$ & $106.0 \pm 0.30$ & $8.65 \pm 0.351$ \\
\hline 4 & $10.30 \pm 0.585$ & $104.0 \pm 0.28$ & $8.05 \pm 0.314$ \\
\hline 5 & $12.05 \pm 0.482$ & $124.2 \pm 0.27$ & $7.78 \pm 0.312$ \\
\hline 6 & $11.39 \pm 0.481$ & $118.6 \pm 0.27$ & $7.71 \pm 0.326$ \\
\hline 7 & $11.25 \pm 0.357$ & $115.4 \pm 0.35$ & $7.60 \pm 0.317$ \\
\hline 8 & $11.22 \pm 0.536$ & $115.0 \pm 0.26$ & $7.70 \pm 0.327$ \\
\hline 9 & $10.35 \pm 0.557$ & $102.9 \pm 0.30$ & $8.18 \pm 0.302$ \\
\hline 10 & $10.14 \pm 0.533$ & $102.7 \pm 0.30$ & $8.25 \pm 0.299$ \\
\hline 11 & $10.07 \pm 0.520$ & $102.5 \pm 0.30$ & $8.49 \pm 0.290$ \\
\hline 12 & $10.01 \pm 0.517$ & $102.3 \pm 0.30$ & $8.45 \pm 0.315$ \\
\hline
\end{tabular}


According to the data, the number of white blood cells in the blood of lambs of all groups was almost at the same level. With the age of lambs it has decreased. The decrease could be followed to the fourth month of life of lambs and in the control group was 7.60; the first-8.00; the second-7.90 and the third-8.05 $10^{9} \mathrm{~g} / 1$.

With the rise of sheep in the mountains, we do not see a significant increase in the number of white blood cells, even there is a slight decrease. But along with this, there were changes in the content of white blood cells in the blood of the control and the experimental lambs. At 4 months of age, the difference between the control and the experimental groups was: the first - 5.26; the second-3.95 and the third-5.92\% in favor of the latter. From the fifth month to the ninth, the number of white blood cells in the blood of lambs of both the control and the experimental groups is almost at the same level, but the difference between the groups remain. In the future, we would observe an increase in the number of white blood cells in all groups, starting from the 9-month age of lambs, associated, apparently, with their winter-stall content. This increase continues until the 11-month of age of the lambs, then there is some decrease in it.

Analyzing the obtained digital data on the dynamics of white blood cells, it can be noted that iodine fertilizing in a certain way affects the content of white blood cells and their increase, while not violating the general pattern associated with seasonality, physiological state and animals' staying at different altitudes above sea level.

The beneficial effects of iodine on morphological parameters of animal blood are evidenced by the works of Lima et al., 1989; Moreno-Reyes et al., 2003; Zagrodzki et al., 2000.

Conclusion Feed iodine supplements had a positive effect on hematopoietic organs: their usage helped to improve the overall condition of the blood: the number of red blood cells has increased by 1.4-6.7\%, hemoglobin-by 5.3$8.8 \%$ and leukocytes-by $4.4-7.6 \%$. The best results on these indicators were obtained in lambs of experimental groups receiving "Yoddar-Zn".

\section{References}

1) Abilov B.T. 2016. The use of iodine-containing drugs in the cultivation of young sheep. Sheep, goats, wool business 2: $35-38$.

2) Gogaev O.K., Ikoeva B.K., Demurova A.R., Ikoeva D.K. 2018. Effect of iodine supplementation on indicators of tushin sheep meat productivity. Proceedings of Gorsky State Agrarian University 55(3): 60-64.

3) Gogaev O.K., Yuldashbaev Yu.A., Kebekov M.E., Kairov V.R., Kaloev B.S., Demurova A.R. 2019. The features of sheep adaptation to their keeping in mountainous conditions. Indo American Journal of Pharmaceutical Sciences. 6(9): 15653-15661.

4) Gogaev O.K., Abaev A.A., Demurova A.R. 2019. The patterns of linear skeletal growth of the crossbred sheep. Indo American Journal of Pharmaceutical Sciences 6(4):8717-8725.

5) Kalanikov A.P., Fisinin I.V., Shcheglova V.V., Kleimenov N.I. 2003 Norms and rations of feeding of agricultural animals Moscow $456 \mathrm{PP}$.

6) Kesaev Kh.E., Gogaev O.K., Demurova, Tskhovrebov A.R. 2017. Age-related changes in quantitative and qualitative indicators of tushin sheep meat productivity. Proceedings of Gorsky State Agrarian University. 54(1): 62-67.

7) Kessaev Kh.E., Gogaev O.K., Bestaeva R.D., Kussova V.A. 2013. Characteristics of muscle growth of peripheral skeleton of young sheep. Proceedings of Gorsky State Agrarian University 50(4): 53-57.

8) Kessaev Kh.E., Gogaev O.K., Bestaeva R.D., Kussova V.A., Demurova A.R. 2011. Growth and development of some muscles in the axial skeleton of sheep's young growth. Proceedings of Gorsky State Agrarian University 48(2): 68-70.

9) Kessaev, Kh.E. Gogaev O.K., Kussova V.A.. 2013 Zootechncal characteristic of sheep among "groznenskaya" breed in the breeding farm "Chervlenye buruny" of Dagestan. Proceedings of Gorsky State Agrarian University 50(1): 134-138.

10) Kessaev Kh.E., Gatsiev U.S., Demurova A.R., Gogaev O.K. 2015. The growth of young Romanov sheep in the foothill zone of the North Caucasus. Proceedings of Gorsky State Agrarian University 52(4): 98-103.

11) Kisinev F. I. 2002. Migration of iodine in the biosphere of the Central Caucasus. The qualitative report. Vladikavkaz. 39: 95-98.

12) Lima, N. Medeiros-Neto G.1989. Transient thyrotoxicosis in endemic goiter patients following exposure to a normal iodine intake. Clinical Endocrinology 21(6): 631-637.

13) Moreno-Reyes R., Mathieu F., Boelaert M. 2003. Selenium and iodine supplementation of rural Tibetan children affected by Kashin-Beck osteoarthropathy. The American Journal of Clinical Nutrition 78: 137-144.

14) Petrov A.K., Gnezdilova L.A. 2015. Effect of iodine-containing preparations on biochemical parameters of blood and fattening indicators of young sheep. Vestnik RUDN. Series "agronomy and animal husbandry" 1 : 48-54.

15) Volynkina M.G., Kazakova N.V. 2013. Use of mineral and vitamin premix "Sanimix" in animal husbandry. Tyumen 168p.

16) Zagrodzki, P. Szmigiel H., Ratajczak Z. 2000. The role of selenium in iodine metabolism in children with goiter. Environmental Health Perspectives 108: 67-71. 